\title{
Threats to the economic security of a digital enterprise in the energy industry
}

\author{
Ekaterina Khusainova ${ }^{1, *}$, Liliya Urazbahtina ${ }^{1}$, Nina Serkina ${ }^{1}$, Regina Salixova ${ }^{1}$, and Zoya Shackih ${ }^{1}$ \\ ${ }^{1}$ Kazan State Power Engineering University, Department of Economics and Organization of Production, 420066, Kazan, str. \\ Krasnoselskaya, 51, Russian Federation
}

\begin{abstract}
The progressive development of regions as open multi-level systems in the context of aggravating contradictions between the interests of economic agents at the stages of deteriorating macroeconomic conditions and intensifying competition at the global and national levels determine the need to form an effective system of economic security at the meso-level, taking into account numerous threats and risk-forming factors. On the one hand, the digital transformation of enterprises provides competitive advantages in the market, on the other hand, it is a challenge that threatens the very existence of the enterprise. The article reveals the features of a digital enterprise through the prism of process vulnerability. Digital transformation creates new threats to economic security. The main specific threats to the digital enterprise are highlighted, as well as the specific industry threats to the digital enterprise in the energy industry. A classification of threats to the economic security of a digital enterprise in the energy industry in an unstable situation is presented, which can be used as a tool for managing the economic security of a digital enterprise.
\end{abstract}

\section{Introduction}

The progressive development of regions as open multilevel systems in the context of aggravated contradictions between the interests of economic agents at the stages of deterioration of the macroeconomic environment and intensified competition at the global and national levels determine the need to form an effective system of economic security at the meso-level, taking into account numerous threats and risk-forming factors. The economic security of energy enterprises is influenced by the general economic situation in the country and in the world.

A global challenge for enterprises in the energy industry is the trend of digital transformation of the industry. Digital transformation implies technical, technological and organizational development, while generating new, previously unknown threats and risks to their economic security.

A situational approach to the study of threats and risks to the economic security of a digital enterprise in the energy industry is implemented in a comprehensive assessment of risk-forming factors, which is a necessary condition for increasing the level of economic security of the state as a whole and its regional formations, neutralizing threats for progressive development.

The purpose of the study is to highlight threats to the economic security of a digital enterprise in the energy industry and present their classification from the position of a situational approach.

\section{Materials and Methods}

\subsection{Brief Literature Review}

The current stage of world economic and social development is characterized by a significant influence of information technologies on it. Digital transformation is the main trend in all spheres of human activity without exception. At the same time, energy, as a basic industry, has been and remains a pioneer of digitalization. The emergence and spread of digital technologies determine the directions of economic development and lead to radical changes for business entities.

Analysis of publications devoted to the conceptual apparatus of the digital economy suggests the formation of at least two approaches to its definition:

1) a narrow approach, assuming that the digital economy is an economy based on digital technologies for the production of goods, the performance of work and the provision of services;

2) an extended approach, according to which the digital economy is "an economic device in which goods and services are produced with a predominant use of digital technologies, and digital data is a key factor in the production of goods and the provision of services" [1]

The second definition is enshrined in the state program "Digital Economy" and in the expert community is also criticized for its limitations. A broad approach may be that the digital economy implies both

\footnotetext{
* Corresponding author: ekaterina0686@yahoo.com
} 
the release of products, goods and services in digital or hybrid form, and the use of digital means of production and enterprise management.

The use of IT in the energy sector in general and in operational dispatch control in particular has historically been a technological necessity. The swiftness of the processes, the gigantic volumes of processed information, the constant complication of the power system - all this led to the active implementation of IT in the operational dispatch management processes. In addition, to ensure the stable operation of the power system and its development, it is necessary to conduct a comprehensive analysis, in which the issues of reliability, efficiency of equipment

The widespread introduction of IT-based technical solutions has become economically profitable; they have become available not only to energy companies and industrial enterprises, but also to retail consumers, small and medium-sized businesses.

The digital economy is based on information and communication technologies. The introduction of information and communication technologies in enterprises has contributed to their digital transformation. Initially, digital transformation was understood as the transition from analog data to digital, i.e. so-called digitalization. This process has led to dramatic changes at the level of business entities, allowing to increase labor productivity in a certain period of time through the transition to new breakthrough digital technologies. The so-called third platform technologies (cloud, mobility, big data) deserve special attention. There is an opinion that it was the technologies of the third platform that led to the digital transformation of enterprises, and the previous technologies only paved the way for the future transformation [2]. Previous technologies did not fundamentally change the organization of socioeconomic relations at the enterprise, did not create platforms for the integration and interaction of all participants in the relationship. They only supported existing business models by fixing processes in electronic form, ensuring the immutability of data, high reliability of their safety.

\subsection{Methods}

The empirical base of the study is data from the Federal State Statistics Service and its territorial bodies, materials from the Ministry of Economic Development of the Russian Federation, the Ministry of Economy of the Republic of Tatarstan, Rating Agency RIA Rating LLC, RAEX Rating Agency JSC (Expert RA), as well as conceptual foundations risk management organizations developed by the Committee of Sponsoring Organizations of the Treadway Commission (COSO), the methodology of the Project Management Guidelines (PMBOK Guidelines), etc. The work was carried out on the basis of collection and generalization (synthesis method), systematization (systemic method) materials obtained from official information resources, analysis of practical experience.

\section{Results and Discussion}

In a competitive environment, operating enterprises have to quickly adapt, optimize and change business strategies and business processes, adjusting to rapidly changing conditions. Digital transformation in this case is:

1) the need to provide competitive advantages in the market;

2) a challenge that endangers the very existence of the enterprise.

The first is achieved by changing the business model, reducing transaction costs by moving to a completely controlled and transparent production process. The second is associated with the need to overcome a number of problems:

- administrative: inconsistency of the current sectoral regulation with the needs of the new technological order and the lack of uniform standards, restrictions on the purchase of foreign equipment and software in the absence of domestic analogues [3];

- financial: the need to divert and invest a significant amount of financial resources for the implementation of digital technologies;

- lack of reliable information, which affects the low level of confidence in digital technologies and the benefits from their implementation, the low level of readiness of business entities to adapt digital technologies [3];

- shortage of highly qualified specialists;

- lack of motivation of the company's management, the need to improve its digital literacy, especially in capital-intensive industries.

The global nature of the problems listed above explains the fact that industrial enterprises before the digital age, with a high degree of conservatism, make decisions about the transition to digital. This thesis is confirmed by a narrow circle of companies that have received positive experience in the complex transition to digital format. The choice of a set of technologies that can solve the existing problems depends on the industry affiliation of the economic entity.

The result of digital transformation is the emergence of the digital enterprise. A digital enterprise is an enterprise with a new organization of activities, with a created digital platform for the integration and interaction of all participants throughout the entire life cycle of the enterprise.

The digital enterprise is characterized by a number of features:

1) the focus in automation is shifting from accounting and control to interaction and integration [4];

2) the approach to process automation is changing: the priority of end-to-end automation and integration of processes based on flexible BPM platforms, BI solutions, omnichannel front-office systems [5];

3 ) the information infrastructure of the enterprise is supplemented: not only local, but also the cloud is used, a hybrid IT landscape is formed;

4) content is being modified: all data is digitized, incl. unstructured.

Digital enterprises create a holistic system in which the boundaries between the supply chain, production, 
contractors, contractors and end consumers are blurred. They use digital technology to improve institutional business models and individual business processes. Here they are faced with the problem of inconsistency of existing systems, methods of data protection with applied digital technologies. Data protection technologies have a large number of limitations and do not keep pace with the development of digital technologies used in the production process of a digital enterprise. The problematic of existing data protection systems is to focus exclusively on incidents within a specific protected system, the focus of attacks on exploiting vulnerabilities of business logic, and not on overcoming protection systems, as well as the probability of instant repetition of the error in many instances [6]. Business processes remain vulnerable, security systems are unable to protect processes. Under the influence of these circumstances, various threats and risks to the economic security of a digital enterprise arise.

Typically, a threat is defined as the direct or indirect likelihood of harm. In a general sense, regardless of the sphere of occurrence, a threat can be defined as "a set of factors and conditions that contribute to the realization of a hazard for a specific object at a certain moment or time interval" [7]

Threats to the economic security of an enterprise can be defined as a set of conditions and factors that create a direct or indirect possibility of causing damage to the resources and capital of the enterprise. Specific threats are based on the above-described features of the digital enterprise (Table 1).
Table 1. Specific threats to the economic security of a digital enterprise.

\begin{tabular}{|c|c|c|}
\hline \multicolumn{3}{|c|}{ Specific threats to the economic security of a digital enterprise } \\
\hline Information capital & $\begin{array}{l}\text { Organizational } \\
\text { capital }\end{array}$ & Human capital \\
\hline $\begin{array}{l}\text { Ineffective use of } \\
\text { information and } \\
\text { communication } \\
\text { technologies }\end{array}$ & $\begin{array}{l}\text { "Collapse" of the } \\
\text { levels of the structure } \\
\text { while lowering } \\
\text { barriers and delays in } \\
\text { the dissemination of } \\
\text { information }\end{array}$ & $\begin{array}{l}\text { Decrease in the } \\
\text { level of personnel } \\
\text { competence when } \\
\text { applying new digital } \\
\text { technologies }\end{array}$ \\
\hline \begin{tabular}{|l} 
The presence of \\
"immature" digital \\
technologies, the use \\
of imperfect \\
technologies and \\
communication \\
channels
\end{tabular} & $\begin{array}{l}\text { Sabotage, accidents, } \\
\text { cyberattacks, virtual } \\
\text { robberies }\end{array}$ & $\begin{array}{l}\text { Psychological } \\
\text { rejection of digital } \\
\text { technologies by } \\
\text { workers of various } \\
\text { levels }\end{array}$ \\
\hline \begin{tabular}{|l} 
Changes in \\
legislation in the \\
field of information, \\
digital technologies, \\
licenses and patents, \\
in intellectual \\
property relations \\
\end{tabular} & \multirow{3}{*}{$\begin{array}{l}\text { Displacement of a } \\
\text { person from the } \\
\text { control system, the } \\
\text { emergence of artificial } \\
\text { intelligence, } \\
\text { robotization }\end{array}$} & \multirow{3}{*}{$\begin{array}{l}\text { Inability of staff to } \\
\text { navigate in a rapidly } \\
\text { changing } \\
\text { environment, } \\
\text { conservatism of } \\
\text { thinking }\end{array}$} \\
\hline $\begin{array}{l}\text { Failure of machinery } \\
\text { and equipment, } \\
\text { safety violations }\end{array}$ & & \\
\hline \begin{tabular}{|l|} 
Growing \\
technological \\
dependence on \\
foreign digital \\
technology providers
\end{tabular} & & \\
\hline
\end{tabular}

Having included the sectoral affiliation of a digital enterprise to the energy industry, we come to the conclusion that a threat is a combination of conditions and factors that create a direct or indirect possibility of harming the digital capital of an enterprise in the energy industry. The main industry-specific threats to the economic security of a digital utility in the energy industry include:

- changes in the regulatory framework of the energy industry in terms of establishing requirements for information systems and software for the energy complex;

- the complexity of the transition to smart grids and digital substations;

- shortage of highly qualified specialists responsible for equipment maintenance.

\section{Conclusions}

Summing up, let's say that in the current economic conditions, it becomes necessary to change the paradigm of economic security of a digital enterprise in the energy industry. It seems appropriate to protect the entire business process, rather than its individual systems or services. First of all, it is required to obtain measurable properties of a process by measuring its individual components and their life cycle. Secondly, to determine the correspondence of the process components to the 
conditional reference process. Third, to determine the legitimacy of the process by comparing the events or processes preceding it. These actions will contribute to the ability to proactively identify threats and risks, preventing the implementation of actions that could cause significant damage to the economic security of the digital enterprise in the energy industry.

\section{References}

1. A.S. Abroskin, Yu. K. Zaitsev, G.I. Idrisov, et all, Economic development in the digital era (Moscow: Izdat. house "Delo" RANEPA, 88, 2019)

2. G. Gruman, What digital transformation really means [Electronic resource] Available at: https://www.infoworld.com/article/3080644/what -digital-transformation-really-means.html

3. Digital transformation of enterprises faces 4 challenges [Electronic resource] Available at: https://ac.gov.ru/news/page/cifrovaatransformacia-predpriatij-stalkivaetsa-s-4vyzovami- 25080

4. A. Golyshko, Different facets of the digital enterprise [Electronic resource] Available at: https://habr.com/ru/post/353864/

5. J. Bughin, J. Manyika, Measuring the full impact of digital capital [Electronic resource] Available at:

https://www.mckinsey.com/industries/technology -media-and-telecommunications/ourinsights/measuring-the-full-impact-of-digitalcapital

6. T. Yapparov, Digital transformation: chances and threats, State and IT business 2 (455) (2017) [Electronic resource] Available at: https://www.crn.ru/numbers/regnumbers/detail.php?ID=117484

7. D. Manannikov, The need to change the security paradigm in the context of digitalization of the economy [Electronic resource] Available at: https://www.econ.msu.ru/sys/raw.php?o=56901\& $\mathrm{p}=$ attachment

8. E.A. Kopylova, Possibilities of applying a situational approach to the analysis of the organization's management system, Economics and Management of Innovative Technologies, 2 (2014)

9. E.A. Napoykina, L.R. Urazbakhtina, G.N. Marchenko, Energy security is the road to the future, Proceedings of higher educational institutions, Energy problems, 11-12, 137-140 (2014)

10. E.A. Napoikina, A.M. Tufetulov, Problems of managing the development of the region, taking into account threats to economic security, Economic horizons, 5 (38), 24-26 (2017)

11. E.A. Husainova, L.R. Urazbahtina, N.A. Serkina, E.A. Dolonina, A.A. Derbeneva, O.V. Filina, Features of management and factors of economic stability of an indusrtial enterprise in the region,
E3S Web of Conferences, International Scientific and Technical Conference Smart Energy Systems, SES 2019, 05025 (2019)

12. A.Yu. Goncharov, Methodical methods of monitoring and diagnostics of balanced regional development, Bulletin of Belgorod University of Cooperation, Economics and Law, $3(55), 324-$ 331 (2015)

13. E.A. Husainova, L.R. Urazbahtina, N.A. Serkina, E.A. Dolonina, O.V. Filina, Monitoring tools of regional economic security, E3S Web of Conferences, 124, 05030 (2019)

14. G.L. Kagan, L.R. Mukhametova, A.Y. Velsovskij, A method for construction of an energy-efficient ice floating peir in the Arctic using hardened ice, Sustainable Energy Systems: Innovative Perspectives (SES-2020), E3S Web of Conferences, 220, $01006 \quad$ (2020) DOI: 10.1051/e3sconf/202017801064

15. N. Yakushev, E. Khusainova, T. Maksimova, L. Badalov, Features of foreign trade between Russia and China and prospects for its development, Sustainable Energy Systems: Innovative Perspectives (SES-2020), E3S Web of Conferences, 220, 01006 (2020) DOI: $10.1051 /$ e3sconf $/ 202022001020$ 